\title{
Evolution of Bantering Spirit in Beethoven and Chopin's Piano Works
}

\author{
Xiaorong Wang
}

Academy of Music, Qilu Normal University, Ji'nan, 250100, China

\author{
Keywords: Haydn; Beethoven; Chopin; Scherzo; Inheritance
}

\begin{abstract}
The history of scherzo can be traced back to the minuet with early court style. In the middle of $18^{\text {th }}$ century, Haydn applied this genre into the $3^{\text {rd }}$ movement of the sonata for the first time. Until the end of $18^{\text {th }}$ century, this genre was continuously developed; on the music master Beethoven's hand, Beethoven started to replace the minuet of large quantity of scherzo, and then greatly expanded the theatricality and satire on the basis of original humorous and deft features, thus the scherzo started to have some features of hero. In the romantic period in the $19^{\text {th }}$ century, the scherzo was evolved into independent single-movement genre on Chopin's hand, and its connotation was greatly expanded and deepened.
\end{abstract}

\section{Introduction}

The history of scherzo can be traced back to the minuet with early court style; the minuet is a kind of triple-time dance music which originates from France with gentle and elegant style, and it is good at describing various kinds of protocol states. In the middle of $17^{\text {th }}$ century, this genre was introduced into the court by French King Louis XIV; since then, the minuet officially became a representative genre of French court dance music. In the middle of $18^{\text {th }}$ century, this genre was introduced into the $3^{\text {rd }}$ movement of the sonata by Haydn, and then the minuet became a kind of necessary genre in sonata-symphony music. After the middle of $18^{\text {th }}$ century, this genre was continuously developed; on the music master Beethoven's hand, Beethoven started to replace the minuet of large quantity of scherzo, and then greatly expanded the theatricality and hero feature on the basis of original humorous and deft features, which expanded a road for deepening the connotation of this genre in the romantic period in the $19^{\text {th }}$ century. While the scherzo was developed into Chopin's era, it didn't simply follow its original meaning, but became a kind of large-scale epic genre with theatricality and hero feature. This paper will start from Beethoven and Chopin's piano works to explore the evolution of bantering spiritual connotation.

\section{Initial meaning of bantering}

The word scherzo firstly appeared in a F-major sonata No.3 (Hob. XVI/9) created by Haydn before 1766. In this work, the $1^{\text {st }}$ movement is allegro, the $2^{\text {nd }}$ movement is minuet, and the $3^{\text {rd }}$ movement is scherzo. This is the only movement which is marked with scherzo in Haydn's piano sonata; with short length and regular structure, this scherzo is a repeated ternary form with only 24 bars.

Schema: Structure chart of the $3^{\text {rd }}$ movement scherzo of Haydn's F-major sonata No.3 (Hob. $\mathrm{XVI} / 9)$

$$
\begin{aligned}
& \text { a b a } \\
& 4+4 \quad 4+4 \quad 4+4 \\
& \text { F-major }
\end{aligned}
$$

The $2^{\text {nd }}$ movement of this sonata is a minuet which is the origin genre of scherzo; in Haydn's sonata, the author makes an obvious distinguishing between these two kinds of genres from perspective of melody lines, features of rhythm and meter, and music personality. The minuet movement adopts 3/4 beats with dance features; the structure adopts traditional repeated trilogy form, the melody lines have flowing dancing feature, and the music personality is gorgeous. However, the scherzo movement adopts 2/4 beats; the melody lines have strong jumping feature, and the music personality is easy and delightful. In this movement, the bantering expresses its easiest meaning. 


\section{Deepening of bantering meaning}

After Haydn, another great classicism composer who made great contributions to the genre of scherzo was Beethoven. At this time, the hot upsurge of the French Revolution swept in Europe, and the great changes happened in the humanistic value of whole society; therefore, Beethoven's scherzo showed endless vitality. In the development process of scherzo, Beethoven played a very important bridge role, and his creation made this genre obtain the perfecting and deepening of content and significance. Although the scherzo didn't appear as independent movement at this time, it laid connotation basis for Chopin to create single-movement scherzo later in terms of conception and scale. Furthermore, Beethoven introduced the scherzo into symphony and made it cause the maximum range of influence; at this time, the scherzo had became a kind of music genre form with quick speed, sudden change in force, and frequent change in tonality. Beethoven's scherzo had different styles; some was funny and humorous, and some was witty and ironic, and his works in middle and later period showed complicated society and hero style. Therefore, in the evolution process of bantering spirit, Beethoven plays a great function and he has made various kinds of exploration for the possibility of "bantering".

In Beethoven's early works, the scherzo shows straightforward feature, and the three sonatas in the work Op.2 created in 1794 1795 complete his initial exploration on bantering style. In the f-minor No.1 sonata Op.2.No.1, the author uses the genre of minuet in the $3^{\text {rd }}$ movement; however, this genre doesn't have its initial feature of dance music, but shows a kind of unpredicted out-of-control feature. This music has lost the dancing feature of dance music; instead, it shows a melody feature which doesn't conform to people's common expectation in inner world. The Germany aesthetician Lips once gave an explanation on common rules of comic feature in the Comedy that the comedy can be divided into two possibility: "one is that a kind of large comedy is expected, but a small comedy appears and it seems that this small comedy comes to meet this expectation; however, on the other hand, due to its smallness, it still can't be shown in a large form.” Therefore, in this movement, the music loses its easy funny factor, and it is deepened as a kind of thought on the aesthetic significance of "bantering", and continues to develop in the $3^{\text {rd }}$ movement of A-major No.2 sonata Op.2.No.2. From A-major No.2 sonata Op.2.No.2, we can see the author's continuous thought on "bantering” features; in this work, the scherzo is clearly marked in Beethoven's piano sonata for the first time, and it still shows the essence of bantering spirit by use of losing balance and breaking people's expectation through sudden changes in melody region.

The establishment of Beethoven's bantering style is in the $3^{\text {rd }}$ movement of C-major No.3 piano sonata Op.2.No.3. This movement contains Beethoven's slight nervousness. The prelude of the music is mainly grown and developed through the main motivation ;ue to adjoining motivation which takes weakness as prefix, the music shows forwarding and positive significance; the author also makes use of the minor second with sharp sound effect, and uses the inconsonant interval relation to enhance fantastic and absurd music effect so as to show bantering feature. This is a very excellent scherzo in Beethoven's piano sonata, and it shows alert, flexible, and absurd bantering effect by use of music language.

Another work which is worth paying attention to is the $3^{\text {rd }}$ movement of D-major No.15 piano sonata Op.28 in which the comic feature of music is naturally expressed. The $1^{\text {st }}$ theme motivation of the prelude delivers a slow and serious music personality; after one repetition, this personality feature enjoys popular support and makes people full of noble and solemn expectation for successive melody. Then, suddenly, the $2^{\text {nd }}$ motivation b which is far from the personality feature of a motivation enters into the music, and the music suddenly becomes clever and lovely personality, just like a child who dresses himself or herself as an adult, an the scene is very funny. The previously formed expectation for "largeness" fails, and the it is met in a form of "smallness"; the bantering of music obtains good effect under this condition.

In the scherzo movement of Beethoven's piano sonata, the exploration and attempt are also made in expressing hero feature via bantering genre, and we can see some traces from falling E-major No.18 piano sonata Op.31.No.3. The scherzo of this work is arranged in the $2^{\text {nd }}$ movement by the 
author; different from the past, this movement uses the sonata form which is good at expressing complicated and contradictory dramatic, epic, and philosophical contents. The music doesn't meet easy expression of deft humor and fun any more, but makes a preliminary exploration on heroic style, thus this music is a work with full heroic spirit and rich fighting color. The work adopts 2/4 beats which are suitable to express marching feature; on this basis, it takes the fractional dot rhythmic pattern as one of dominant motives and uses the quick and powerful low-voice jump tone so as to endow the music personality with a kind of structured, strong, and excited alla Marcia and take this feature to highlight the bold, powerful, and positive heroic feature of the music.

\section{Expansion of bantering meaning}

After entering into the romantic period, the scherzo gradually becomes a kind of independent single-movement genre, and Chopin's four scherzos also expands a wider space for the connotation of bantering; in his works, the heroic and lofty features obtain incomparable position. His music abandons the well-balanced structure and orderly syntax in the classicism period, only takes the musical structure in classicism period as an initial carrier, and carries out various kinds of changes according to the demand of creative thoughts. From this point, it can be seen that his works have made breakthrough exploration on musical form; however, the heroic thought in his scherzo is the inheritance to Beethoven's scherzo. In Chopin's four scherzos, three of them use the minor. In the romanticism period, as more and more attention is paid to music chromaticity, the minor gradually plays a more and more important role; Chopin's four scherzos mainly tell his missing to hometown and relatives, some social events, and his complicated, wandering, and sensitive emotion, thus the minor adopted in those scherzos also shows powerful era pulsation, which is a feature not existing in the Beethoven's scherzo. Chopin's scherzos make full use of color features of minor to highlight the "dramatic" connotation of scherzo, and the connotation of scherzo is ascended to a layer of including the complicated conflicts of society and history. In his scherzos, the hero image shaped is very humanized; except for retaining the step of bravely moving forward, there is also hard growth process. We can obtain deeper value experience from Chopin's shaping tragic hero.

Grout says in his book History of Western Music: "The basic feature of Chopin style is large-area elaboration in ballade and scherzo. The main scherzos include b-minor (Op.20) and rising c-minor (Op.39). Chopin's scherzos have no original naughty sense of this genre, and they are all serious works with sufficient energy and passionate emotion; just as ballade, the scherzo is naturally produced from musical thinking in a tight form." Grout thinks that the $1^{\text {st }}$ and $3^{\text {rd }}$ scherzos in Chopin's four scherzos can better stand for his style, and these two works are the best explanation to "heroism". These two works are respectively born in two depressed periods in Chopin's life, and they contain certain tragic color. The most valuable thing in the tragedy is people's desire for survival and vigorous vitality while people suffer hardship and destruction, that is to say, the supernormal resistance consciousness and firm and persistent will showed by the subject, which is the hero and lofty feature we say. Lips tragedy shall follow a kind of blocking rule, and he says: "The disaster can enhance the sense of value, which is realized according to a common rule. I generally call this rule as 'psychological blocking' rule: as for psychological change and representation series, in their natural development, if they suffer restriction, barrier, and blocking, the psychological movement will be blocked and keep standstill, and then the degree is improved in the place where the restriction, barrier, and blocking happen.” The application of blocking rule in the music is very common, and the specific ways of creation include: causing the sense of obstruction via sudden break-off of rising or falling of melody line, causing the feeling of tension via non-harmonic tone, and causing the sense of restriction via delaying the solution of inconsonant chord. In Chopin's $1^{\text {st }}$ and $3^{\text {rd }}$ scherzos, the tragic expression of music is completed according to blocking rule. In the falling b-minor No.1 scherzo (Op.20), the theme melody has determined its tragic color at the beginning, and the phrases are mixed with large quantity of heavy-category leading note and auxiliary leading note, and the up and down motion at melody line causes great sense of barrier. As for another work rising c-minor No.3 scherzo (Op.39), it has completed this blocking rule at the introduction part. In the 3/4 beats of rhythm, the quadruplet 
and lots of not solved leading notes are arranged; after the seeking motivation in the introduction park, the not solved leading chord is arranged; those technical arrangements can cause emotional blocking and separation. However, the heroic feature of music works shall be realized via resisting against tragic emotion. In the falling b-minor No.1 scherzo (Op.20), although the melody line is winding, it always takes upward marching as main direction; in the rising c-minor No.3 scherzo (Op.39), although the melody line is under down direction at the starting part of theme, the melody line of later paragraphs moves upwards in an extremely slow gradient, which causes a kind of hard fighting sense, thus the heroic feature of work is just expressed in this way.

\section{Conclusion}

The genre scherzo has had hundreds of years of history since its predecessor minuet; in this process, the changes always happen in its connotation with the change in the era features. In the process from easy and funny music to the long-length epic with tragic and heroic features, this evolution process condenses the social changes and also contains the transition in era style. The rising and declining of a genre are just like the changes in life; from the initial establishment, to formal maturity, and to collapse of appearance and reservation of connotation, all things follow this historic rule. As for musicology researchers, to understand those changes can help them to master common features and rules of musicology development in a more effective way.

\section{References}

[1] Liu Xiaofeng's Selection: German Aesthetics Selected Works, Shanghai: East China Normal University Press, 2006.

[2] Written by Li Xingchen: Course of History of the Western Aesthetics, Beijing: Peking University Press, 2005.

[3] Written by Qian Yiping, Wang Dandan: Evolution of Genre and Form of Western Music, Shanghai: Shanghai Conservatory of Music Press, 2003.

[4] Li Juan: Historical Evolution of Scherzo and Its Bantering Spirit, Nanjing: Nanjing University of the Arts, 2007.

[5] Shan Lin: Scherzo and Its Bantering and Bantering Spirit, The New Voice of Yue-Fu (The Academic Periodical of Shenyang Conservatory of Music), 1994 (3).

[6] He Shangfeng: Chopin’s Contribution to Scherzo Genre, Musicology in China (Quarterly), 2005 (1).

[7] Yang Yandi: Humor in Music, Music Lover, 1995 (2).

[8] Chen Jingyu: From Artistic Ontological Meaning of "Bantering” to Humanized "Bantering Spirit”, People’s Music, 2011 (2). 